\title{
Blowing specific words : verbal charms as material suspended events
}

\section{Siragusa, Laura}

2021-07

Siragusa, L \& Zhukova , O Y 2021, ' Blowing specific words : verbal charms as material suspended events ' , Multilingua , vol. 40 , no. 4 , pp. 463-485 . https://doi.org/10.1515/multi-2020-0049

http://hdl.handle.net/10138/334676

https://doi.org/10.1515/multi-2020-0049

publishedVersion

Downloaded from Helda, University of Helsinki institutional repository.

This is an electronic reprint of the original article.

This reprint may differ from the original in pagination and typographic detail.

Please cite the original version. 


\title{
Laura Siragusa* and Ol'ga Yu. Zhukova Blowing specific words: verbal charms as material suspended events
}

\author{
https://doi.org/10.1515/multi-2020-0049
}

Received March 25, 2020; accepted December 13, 2020; published online December 25, 2020

\begin{abstract}
This article undermines the actuality of a strict boundary between language and materiality by presenting verbal charms (puheged, vajhed/pakitas in Vepsian) among Veps, an Indigenous minority group of Northwest Russia. Vepsian verbal charms are ritualized ways of speaking that are customarily used to prompt a change in both human beings and environments in very tangible ways. When observing how they are conceived, distributed, and performed among Veps, the rigid separation between "material" and "immaterial" realms begins to be felt as an artificial construction, since Veps understand that in the act of "blowing" air accompanied by the recitation of "specific words," human and often non-human agencies join forces to promote changes in people and the environment. This paper engages not only with the academic interest in the material intersections between language and the world (see, Cavanaugh and Shankar 2017; Keane 2008a; Wiener 2013, to name a few), but also aims to reframe the notion of "event" as a transformative and suspended encounter between human and often non-human agencies (Kapferer 2015) and thus deepen our understanding of what living relationally might entail.
\end{abstract}

Keywords: event; human and non-human agencies; language (and) materiality; Northwest Russia; Veps; verbal charms

Чудо не духовно, оно всегда материально.

[R. Wonders are not airy, they are always material.]

(Bogoraz 2019: 19)

\section{Introduction: language materiality in verbal charms}

Is the separation between language and materiality truly insurmountable in academic discourse and consciousness, as Irvine (2017:277) remarks at the beginning of her

*Corresponding author: Laura Siragusa, Faculty of Arts, University of Helsinki, Helsinki, Finland, E-mail: laura.siragusa@helsinki.fi. https://orcid.org/0000-0001-6991-2313

Ol'ga Yu. Zhukova, Petrozavodsk State University and Academy of Sciences, Petrozavodsk, Russian Federation, E-mail: olgazhukovaveps@mail.ru 
afterword in Cavanaugh and Shankar's edited volume (2017), Language and Materiality: Ethnographic and Theoretical Explorations? Indeed, this appears a rather challenging task given that even the discreetly agreed monism - where anthropologists assert that language and materiality can be juxtaposed as a wholeness (Nakassis 2013: 400) - is often based on such a presupposed dualism (Irvine 2017: 277). In recent years, the study of language (and) materiality among anthropologists has developed into a rather manifold scholarly platform, where different approaches to such an inquiry have emerged and to a certain extent complemented each other. In 2012, Shankar and Cavanaugh (2012) brought all of these multiple directions into dialogue, indicating which scholarly endeavors had been more successful and debated. They disclosed that the main academic trends in language (and) materiality had thus far investigated the "material conditions of language use" (Shankar and Cavanaugh 2012: 355). These were manifest in semiotic approaches (Keane 2003; Kockelman 2006; Silverstein 2003), language ideologies (Kroskrity 2000; Schieffelin et al. 1998), intertextuality and interdiscursivity (Irvine 2005; Silverstein and Urban 1996), embodiment (Gal 1991; Taylor 2013: 101; Weidman 2014), circulation and biographies of texts (Hull 2003), and recurrent syntheses among them. In 2017, these trends provided the basis for the structural organization of their edited volume, implicitly acknowledging their yet dominant position in current scholarship. Interestingly, while in their 2012 review, Shankar and Cavanaugh advanced the use of the phrase "language materiality" (2012: 356), in their latter work, the conjunction "and" (already in the title of the book) appears more prominent, thus subtly indicating how problematic the task they set themselves to erase such a polarity has proven to be. In our work, we aim to enter into dialogue with this fairly new and dynamic field of research, by presenting an ethnographic case and its consequent contribution to this debate, which, in our opinion, has only marginally been addressed and instead might add a new perspective to such an intellectual conundrum.

Our point of departure is founded on an emic approach to research, which indeed concurs with Irvine's final suggestion to rethink the notions of language and materiality, "when considering ethnographic cases in which there is no such opposition - or perhaps a differently imagined opposition - between language and materiality" (Irvine 2017: 277). By reconsidering the dualism between language and materiality through an analysis of verbal charms, we study not only their textual, linguistic, and semantic value, but also their social and relational qualities. ${ }^{1}$ This allows us to deepen our understanding of what living relationally means through material relations constituted by and through language. In our paper, the phrase

1 We have opted for the term "verbal charm" in our paper. However, in the literature these are variously called, e.g., spells, incantations, and enchantments. 
"language materiality" refers to both the ritualized embodied experiences of communicative practices, which have the potential to alter the world, and the metaphor of specific words as physical and material. "Language materiality" not only encompasses a phenomenological approach to ritualized communicative practices, focusing on the embodied participation and experiences of the person uttering the words and their recipients, but it also extends to the effectiveness and causality of the utterances as they can have consequences, which are visible, tangible, and material in the world. In the context of the presented verbal charms, "language materiality" is manifested progressively as an extended, suspended event, in which the materiality of the words, which are understood to have weight, enters into unison with the material characteristics of bodies and substances. It is under specific circumstances, i.e., in the blowing of specific words, that different materialities (i.e., of words and of other substances and bodies) mingle and unify. It is in this encounter that they have the potential to prompt change. The phrase "language materiality" covers an ontological conceptualization of specific ritualized words, which while bearing weight, are blown onto other materials and substances.

\section{Verbal charms as material suspended events}

Our paper introduces (the use of) verbal charms (puheged and vajhed/pakitas in Vepsian) among Veps, a Finno-Ugric indigenous minority, living in Northwest Russia. While in the case of puheged, our focus is on the act of blowing words as a way of engaging with both human beings and the environment, in the case of vajhed/pakitas, we focus on the capacity through words to make changes in the environment and their relationality with other-than-human entities (e.g., the territory masters). When addressing both practices without making specific reference to their distinctions in use and function, we will use the syncretic phrase "blowing specific words." Indeed, our case concerns ritualized "language," which in other works - both classics and more recently published works - is often referred to as "magic" (cf., to name a few, Golopentia 2004; Malinowski 1935; Mauss 2001[1950]; Ryan 2004; Toporkov 2012). We distance ourselves from the term "magic" since it hints at the existence of an unworldly, immaterial, and parallel dimension, where invisible powers come into scrutiny - a position which we dispute.

Through an analysis of Vepsian verbal charms, we reconsider some of the previous research within the frame of ritualized communicative practices, which have either been left at the margins or partly engaged with the notion of "language materiality" - a rather recent conceptual contribution to linguistic and anthropological analysis. In particular, while reference to causality and effectiveness concerning verbal charms has partly been addressed in the literature, albeit often 
not framed as "language materiality," an ontological conceptualization of ritualized words as materials has yet to be provided (cf. Ferguson 2019 on an ontology of words). Quite often among indigenous peoples, the movement of air in the form of breath, smoke, and fumes is understood to have a transformative and generative capacity (cf. in other parts of the world, Fienup-Riordan 1994; Handelman 2005; High 2018; Rahman and Brabec de Mori 2020; Siragusa et al. 2020). Already in 1922, in his iconic work, Argonauts of the Western Pacifics: An Account of a Native Enterprise and Adventure in the Archipelagoes of Melanesian New Guinea, Malinowski explains how the construction of a canoe is accompanied by the performance of verbal charms, which help its actualization (Malinowski 1922: 95-112). The charms also guarantee that plants and gardens flourish (Malinowski 1935). In approximately the same years, in his lecture course, Vladimir Bogoraz - the father of Soviet Anthropology - explains how among Chukchi, indigenous peoples of Northwest Russia, hunting happens collaboratively between male hunters and female sorcerers, who by casting spells into the fire, "attract the game to the heart, which is the center of life" (Bogoraz 2019: 140). ${ }^{2}$ The combination of these actions potentially secures a successful hunting session. Even though he did not directly engage with the notion of "language materiality" as causality, in the excerpt he indirectly hints at it. Likewise, in his work among Nuer, Evans-Pritchard (1956) explains how in Sudan God is air, and as air he is also the creative spirit, that is, in God/air things begin to take shape. These pioneering anthropologists show that they had developed a strong sensitivity to local practices when they illustrate the material causality that resides in the verbal charms, although they do not make any direct reference to this causality. Admittedly, Bogoraz suggests a new conceptualization for ritualized language and that different metaphors and language ontologies should be taken into account when thinking of their materiality. He intuitively advances the fact that words might have material connotation themselves, and that the shamans "have such a magical formula, which, being verbal, has some kind of material objectified form” (Bogoraz 2019: 144). This observation, nonetheless, was not taken up by other Soviet or Russian scholars and remained constrained to this first explanation. In light of the recent discussion on "language materiality," we thus make some initial attempts to investigate not only the motive of causality, so dominant in pioneering and current anthropological work, but also different metaphors attached to the ritualized words and language and their embodied experiences in the world.

When turning to the actual performance of the charms (both puheged and vajhed/pakitas), the participation of body parts, substances, and other materials

2 The original in Russian is “...привлекают к очагу, - который является центром нашей жизни, - зверя.” 
become paramount in their effectiveness. So, when taking into account the objects that are used during the uttering of the verbal charms, we also treat previous research as our starting point, while pointing out the similarities and differences between our approaches. Reference to body parts and objects during the performance of verbal charms has been regularly made by other scholars, who often credit them as accompanying tools and only subtly allude to the plasticity of matter, while "blowing specific words" with force onto them. Malinowski (1922: 154), for example, shows that during the release of the first canoe among Trobrianders, "substances" are used to convey the spells successfully, which, however, he refers to as a "rite of transference." Here the force of the words is not directly performed on the recipient object, but rather on a "special medium, used to absorb the magical force, and to transfer it to the final object” (Malinowski 1922: 315). In his description, he seems to keep matters separate, whereas, in the present work we want to stress that the objects, body parts, and tools used in the ritual, which are initially separate, then merge during the act of blowing specific words. Similar examples come from different parts of the world (most often among indigenous groups), where either substances, food, and different objects are known to attune with the resonation of the words, the act of blowing, drumming and smoking, and thus to make it possible for the verbal charms to be effective. In his work in Nepal, Desjarlais (1996: 148) explains how the performers of healing spells use drums, which they lower closer to the food (e.g., milk, meat, egg, and curd). The patients are then asked to eat this food, which will help them reincorporate lost vitality and regain strength. Similarly, in Tibet pills are used on ritual occasions, as part of empowered substances called "jinden" (Prost 2008). Still concerning food, but also other substances, the work by Stewart and Strathern in the Pangia area in Papua New Guinea shows that there used to be two types of sorcery in the 1960s:

in one type, called tomo, the sorcerer was thought to slip lethal substances directly into people's food, causing them to become ill and die unless purgative medicine along with a spoken spell could be administered in time by a trained curer. In the other type, nakenea, someone with a grudge against the victim was said to pick up a part of their life-force held in a piece of clothing (such as a hair) or food remnant (an incompletely eaten piece of food) and to take or send this to an expert sorcerer living some distance away. [Stewart and Strathern 2012:6]

In this case, food, body parts, and clothes are used to affect one's well-being. In Brazilian anthropology, Taylor also demonstrates that while scanning the body of the patient, the healer:

begins to whistle and hum, and then starts to sing, first softly then loudly, to summon and communicate with his helper spirits and the stock of magic darts he keeps in his saliva or phlegm, figured as an inner pond (kucha or cocha, Quichua for "lake”). [Taylor 2013:101] 
Weiner (1983: 692) refers to this encounter of air and matter, in the form of food or other substances, as an "invasion of personal space." In his opinion, the words uttered during the spell "penetrate one's own personal space," and this can only occur "in relation to the hardness of the words spoken, the heaviness of the objects that are given, or the rarified circumstances under which magic spells are performed” (Weiner 1983: 692). Frog (2013: 63) makes a similar observation when assessing the Finno-Ugric “tietäjä-institution," which he claims "maintained a model of the penetrable body to which illness and harm was caused by the penetration of the body." Their reference to "penetration" and Malinowski's (1922) "transference" are closer to our conceptualization of charms as events than other terms and explanations used in the literature, where the objects are simply described as accompanying tools (Panina 2014: 120; Ryan 2004: 117). Separatist positions like these have allowed for claims where objects are seen as "having their own magical qualities" which the healer can take advantage of when casting the spell (Mauss 2001[1950]: 59). We would argue that, while objects, tools, substances have their own objective material composition and qualities, these attune with the materiality of the specific words, which bear weight themselves, once they are uttered and the forceful movement of air is blown. We suggest that it is the whole practice, encompassing the material separation between words, objects, substances, and the breath, the act of forcefully blowing out specific words that can have a visible and tangible effect on life.

Embodied experiences of verbal charms occur from the moment one receives the specific words, to the moment the words are uttered and their effect is manifested (although on occasion, it may not). Given this prolonged period of time, we refer to the verbal charms as suspended events of a transformative nature (cf. Kapferer 2015), in which the act of blowing is crucial in unifying and merging different materials (the specific words and other substances and objects). In such a suspended condition that is extended in time, human (collective) intentionality joins non-human agencies, and the boundaries between language and materiality appear feeble, if not non-existent. When the channels of communication between the sorcerer and other forces are open, the boundaries between language and materiality appear to blur, forming a new condition where change is possible. Such a condition is spurred by the act of blowing specific words and the consequent movement of air. This is what we call an event, that is, a suspended condition that is extended in time, where human (collective) intentionality joins non-human agencies, and where the boundaries between language and materiality appear feeble if not non-existent. Social change and renewal ensue in the space between the physical body of the sorcerer, with particular reference to the mouth as the body part, which is liminal between the human and the non-human dimension (cf. Strogal'shchikova 1988: 98) and the actualization of the request. Once a 
request materializes in a clear result, the event is complete, and this recalls what Keane (2003) calls “causality” or "thirdness" with reference to Peirce. Indeed, the verbal charms create expectations, and so in the present moment people project themselves into the future, as if suspended in an unresolved condition, where change is occurring but its result is not yet available to the sight or any other sense. Between the ritualized performative act and the moment when a result becomes apparent, people live "as if" in a prolonged period of suspension, during which they wait for an answer. The verbal charms and the ritualized actions surrounding the actual utterance of the texts often exist in the encounters between human and non-human agencies, which "open up contingencies and processes of life, rather than cutting up the world into inert natures" (cf. Arzyutov 2019; Barua 2016: 269). Such interactions and intersubjective fields (De Castro 1998: 471) are thus "social-actional events" (Silverstein 2003: 202) of a transformative and generative nature (Kapferer 2015), which in every step of their execution evokes questions of "language materiality."

\section{Carefully speaking Vepsian in multilingual Northwest Russia}

Veps are a Finno-Ugric indigenous minority of Northwest Russia, a multi-ethnic territory, where Russians and Karelians also hold the status of being indigenous. More precisely, Veps gained the status of indigenous minority groups of the Russian Federation in 2000 (Strogal'shchikova 2016). According to the last census, in 2010, the Vepsian population counted 5,936 individuals (Strogal'shchikova 2016). Even though Veps traditionally live in rural settlements surrounded by the boreal forest, swamps, rivers, and lakes in the Republic of Karelia (northern Veps), the Leningrad oblast (western central and southern Veps), and the Vologda oblast (eastern central Veps), in recent years the situation has changed. While until 2002 the rural population outnumbered the urban population, this demographic condition was reversed in 2010, possibly due to the historical developments of the last century, which witnessed two World Wars, Stalin's terror, assimilation policies, and mass urbanization (Strogal'shchikova 2016). Just like other parts of Russia, this northern territory is extremely polarized in terms of urban and rural settings, coupled with distinctive practices and their social and cultural symbolism (Siragusa 2017, 50-51). Verbal charms which have emerged in such a rural and forested territory in relation to its human and non-human inhabitants, are still exercised in some villages where Veps live, whereas they have become irrelevant or even obsolete in urban settings (Siragusa, fieldnotes 2013, 2015; Siragusa and Zhukova, fieldnotes 2018). 
Practicing verbal charms is not limited to Vepsian villagers in Northwest Russia. Given the long-term contacts among the different populations dwelling in this land, many practices (including certain language practices) have moved and become part of a joint ontology among Vepsian, Karelian, and Russian rural dwellers. Supported by assimilation policies, the elderly Vepsian villagers (from 65 years upwards) have normalized multilingualism, as they tend to be fluent in Vepsian and Russian, a Finno-Ugric and a Slavic language respectively, and engage organically in codeswitching practices (Puura 2018; Siragusa 2017, 114-120). Middle-aged urban Veps tend to speak mostly Russian, unless they have studied Vepsian at school and university, matching the goals of the Vepsian language revival, which commenced with perestroika and glasnost in the Republic of Karelia. It is thus not surprising that the verbal charms, which are divided into zagovory and zaklinaniya in Russian, correspond to the distinct Vepsian puheged and vajhed, pakitas. In fact, while the majority of Vepsian verbal charms are retained in the Vepsian language, some might also be in Russian.

In such a multi-ethnic and multilingual territory, stereotypes are often used to characterize and distinguish the different groups. Among other connotations, Veps are stereotypically described and describe themselves as "careful" people (Siragusa 2017: 50). Such a description extends to Vepsian ways of speaking, which are often pondered carefully, so as not to cause offense to either human or nonhuman beings (Siragusa 2017: 10, 22, 85). Such a carefulness also applies to verbal charms. It is as if a grading of carefulness has to be applied to different ways of speaking, depending on how vigorous their use and execution can be in the relations with both human and non-human entities. While everyday speech aims to guarantee a peaceful living with other human and non-human beings, based on relations of respect; vajhed/pakitas - specific, special words - have more weight and their use has the potential to affect changes in the world; and in the act of blowing words during puheged, the material words and other materials merge and unify. For this reason, while the vajhed/pakitas are used by all the villagers, only designated ones, called tedai, are able to engage in puheged. ${ }^{3}$ The specific words

3 Not all tedajad (pl. tedai) self-identify as knowledgeable persons. The issue of self-identification on behalf of sorcerers or knowledgeable individuals has been raised by other scholars. Agapkina et al. (2003: 14-15) claim that almost everyone in the Russian villages where they work knows a few zagovory. On some occasions, the local villagers would have memorized up to 60 zagovory and yet deny self-identifying as sorcerers. Similarly, Lavonen (1988: 136) mentions that in his experience some people in the villages had learned some zagovory but did not consider themselves sorcerers. This used to be the case in France, too. Favret-Saada (2015[2009]: 12) stresses the fact that the "antiwitches" did not think of themselves as sorcerers, but more like people who "do things." Thus, they stressed the material and transformative efficacy found in the ritualised powerful words more than focusing on the identity of the people who spoke them. 
have weight, they are spoken of as tangible and material and when blown in the ritual acts, their materiality seems to dissolve and merge into a new reality with the materiality of the substances and objects on which they are uttered.

In general, the puheged cover specific functions, which are mostly related to life in the village. They appertain to human-to-human relationships, health, and human and other-than-human relationships. Indeed, they can be used for healing purposes: curing hernias, bleeding, earache, and any sickness brought about by territory masters. They can be used to protect and look after children. Some are used to make people fall in or out of love. The Vepsian words puhe, puheg have direct reference to the movement of air as a way to participate in life and interconnect with the environment more deeply, as well as be part of a meshwork of sentient beings (both human and non-human). The word puheg is etymologically related to the verb puhuda (to blow) and the noun puhutuz (whiff of wind), which leads us to interpret puheged as a way to intervene in certain pressing situations through blowing and the movement of air. "To cast a spell” in Vepsian is translated as puhuda puhegid (literally, to blow verbal charms). Among the southern Veps, puheged are also called puitoomižed from the verb puiteida/puitooda/piiteida (to cast a spell). While the etymology of puitoomižed is not entirely clear, we can assume that it is related to the Finnish verb puittaa with the meaning of "to run fast, to run away" (SSA 1995: 417). In many proto-Finnic languages, such a verb encompasses the connotation of "jumping from branch to branch," and is used with reference to the movement of squirrels. A similar word with the same roots is also found in the Inari Saami language, puited, which besides this meaning, conveys the significance of "saving oneself from a given situation by saying something" (SSA 1995: 417). The term puiteida/puitooda/piiteida could also be etymologically connected to the Finnish verb puida, which means to separate the grain from the chaff and might also recall the word winnow, i.e., using the wind to separate the grain from the chaff (see, https://www.kielitoimistonsanakirja.fi/\#/puida). Overall, we can assert that the act of blowing while uttering some words and the (fast) movement of air/in the air may contribute to affect a problematic situation and possibly get rid of what is unnecessary, undesired, and useless. Another way to invoke spells is through the employment of vajhed and pakitas, which literally means "specific words" often to "make a request" or "summon a favor." They are used to come to terms with the territory masters concerning the produce found in the domain they control, building a house, having a successful hunting or fishing session, protecting the pasturing cattle, and so on (Makar'yev 1932: 36-37). In their use and functions, these verbal charms correspond to those called zaklinaniya in Russian (cf. Agapkina et al. 2003; Ivanits 1989: 111). Veps accept that both puheged and vajhed/pakitas allow for a change and transformation either in fellow humans or in the environment. While Laura has not witnessed the actual 
delivery of any puheged, since these often occur in the evening and privately, Olga has while living in the village; and we have both witnessed and assisted at the use of vajhed/pakitas. We have also been able to gather oral history concerning people who had been cured, cured a sick person, or made use of the charm to intercede in some human-to-human relations.

\section{Vajhed/Pakitas to co-exist respectfully}

If directly asked whether or not the territory masters occupy and have control over certain territories, the responses Veps provide might differ. Those who are either influenced by ideologies of progress and evolutionism or simply abstain from sharing a certain knowledge, often confess "not to believe" in such faiths. Others, in contrast, more openly admit that "there is something out there." If these responses often match a rural-urban polarity and their concurrent ideologies, the engagement with the territory masters seems to level such a dualism. Indeed, regardless of the opinion one might have towards the very existence of the territory masters, urban and rural Veps tend to engage in practices of respect and carefulness towards them. Those also include verbal practices. For example, in the forest or in the kül'bet' (Vepsian sauna), one should not swear or scream. When entering the forest, one might ask - loudly or silently - for permission to gather the produce found there, by touching a tree and uttering the request. A similar behavior is displayed when one leaves the forest (Siragusa, fieldnotes 2011) and when one goes fishing (Vinokurova 2010).

Indeed, questions of being and co-existence with other-than-human (often spiritual) entities have been largely studied in anthropology, where animism became a popular field of inquiry as early as the end of the 19th c. In most recent decades, it has taken ground again (to name a few, Bird-David 1999; Brightman et al. 2012; Descola 2014; Latour 2009; de Castro 1998; Willerslev 2007). In our work, we focus on the presence and agency of non-human entities through a study of language in the form of ritualized verbal art. Not only other-than-human agencies affect the verbal choices humans engage with in order to reach out to them, but they are also understood to provide responses that affect people's participation in life. The consequences of the verbal charms in which the territory masters are invited to participate are material and are understood not to depend only on human (collective) intentionality.

The first pakitas we present, which literally refers to making a request to the territory masters, is taken from the phono-archives in Petrozavodsk, the capital of the Republic of Karelia. These entities are often territory masters, that is powerful forces who control a given territory, such as the mec(a)ižand and mecemag (host and 


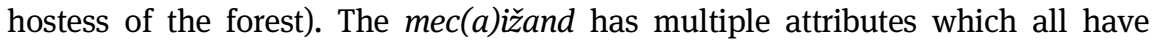
reference to the mec (forest), i.e., mechine, mecamez', and mecuk. In some villages, such as Pondal (a central Vepsian village), the mec(a)ižand is also referred to as toine pol' or toine čura, which literally means the “(on) the other side." Other territory masters comprise the vedenižand and veden emag (host and hostess of the water), the kül'betižand and kül'bet'emag (host and hostess of the kül'bet', Vepsian sauna), and pertinižand and pertin emag (host and hostess of the house and land on which it is built). Through blowing specific words, the tedai opens channels of communication with such wide-ranging entities. These verbal charms usually have a freer structure than puheged, although at the beginning they tend to address the territory masters and then make either a request or show their gratitude. In this audio recording, the interviewee also contextualizes the actual specific words one should utter by providing a description of the steps to take when looking for the right piece of land for building a house:

Konz pertin stroidas miččele sijaižele, ka ottas siu sijoupei mad (nece endou). Kuume kerdad näpižuu lendeltas i pakitas:

Man ižandaine, emagaine, Uidihikat neciš horomeižes, Nügüd minä stroiškamoi. (ičeze nimen sanutas), $\mathrm{Nu}$, ka kut voiškab-ik kerata,

Voiškab - ka ozutade ves'oudan, hüvän. Ii voiška - ka prämo kükso mindain. Uniš ozutaso hiile, ku küks' - ka ii pangoi sinna sijale pertin.
When considering where to build one's house, one takes some soil in the hands and asks three times:

Host and hostess of the land, Leave this mansion, Now I'm going to build. (and says his/her name), So, if it is possible to do this [i.e., build the house],

If it is possible, then be cheerful and good. If it is not possible, then chase me away. The answer appears in their dreams. If they are driven away, they will build somewhere else.

[KRC-RAN 19-2663-22]

The response from the territory masters, which in this case appears in one's dream, determines how one will consequently behave in the world. The vajhed/pakitas event extends to the moment when one obtains a reply and can thus take the necessary steps to comply with mutual concord. Most Vepsian villagers accept that they co-exist with other forces, with whom they need to negotiate how to participate in life in order to secure a quiet living. A quite living, indeed, is sought not only by making a request but also by showing gratitude after an action has been taken in a territory occupied by the masters. In the next vajhed, one demonstrates gratitude for the use of the kül'bet' (Vepsian sauna), which in the villages is usually heated on Saturdays: 
Kül'bet'ižandeižed, emägeižed, Spasibo žaruižuu - paruižuu, Pezetamižuu, Valatamižuu, Sobitamižuu!
Hosts and hostesses of the sauna bath, Thanks for the heat and steam,

For the wash,

For the shower, and dressing!

Zhukova personal archive. 2017. Kurb. Zhukova interviewed A. I. Zaretskaya (1935-).

In the villages and the surrounding forest, swamps, rivers and lakes, a respectful co-existence with the territory masters is desired, and uttering vajhed/pakitas is understood to be a way to guarantee it. Very often the recitation of these specific words is accompanied by physical participation, too, by touching the water, the trees, and so on. These brief ritualized events occur all the time, as the villagers dwell in this rural environment. Contrary to the puheged, which require the intervention of a tedai or any knowledgeable person, the vajhed/pakitas are practices by anyone who lives in or often visits the villages and has been told how to behave correctly in this territory.

\section{Puheged: blowing specific words}

Those who hold the knowledge of the specific words choose to whom they are going to give (antta) them and who is going to become a tedai next. As soon as old age arrives and personal strength fades, the elderly tedai will look for someone to "take" (otta) the specific words and continue the practice. It is common knowledge that when the tedai has lost many teeth due to old age, he or she will not be capable or strong enough to perform the verbal charms anymore. The teeth are thus also an essential material part of the ritual. During our research, some of those knowledgeable villagers admitted to not having "given" (antta) the words and shared their knowledge (tedo) with anyone yet, since they are still able to execute them (Siragusa, fieldnotes 2013). One of the criteria to select an apprentice is that he/she has dark eyes, as these are understood to indicate more strength (Siragusa, fieldnotes 2015). Interestingly, when a tedai approaches old age and begins to teach verbal charms, what he/she claims to pass on is the tedo (knowledge) of those specific words, not their power. Contrary to the Finnish and Karelian folklore traditions, where the words in the verbal charms are understood to bear "power charge" (väki) (Stark-Arola 1998: 113, 120), the correspondent Vepsian term, $v a ̈ g i$, is not used with reference to the enchantments. Instead, Veps speak of those words as if they bore weight themselves, and that one can give (antta) and take (otta) them with the purpose of helping others in time of need. Retaining those words is not guaranteed, even if one has been given them. During 
an interview with Lara Mironova (pseudonym) in Pondal in 2013, Laura was told that one can remember only those words which resonate with them. ${ }^{4}$ In other words, not all the charms can be "taken" and memorized - "those who are 'yours' will be easy to remember, and you will forget those who are not 'yours', no matter how many times you try to learn them" (Siragusa, fieldnotes 2013). The apprentice often writes these words down on pieces of paper, which are kept in chests of drawers, often in the sitting room and taken out to be revised when summoned by someone in need. While learning the specific words by heart, since these cannot be read during the delivery of the verbal charms, the apprentice might simultaneously eat bread so as to assimilate and fully embody the words (Siragusa, fieldnotes 2013).

Learning the specific words does not suffice to guarantee a successful verbal charm. Indeed, the tedai should follow certain steps when his/her intervention in a certain matter is requested in order to be ready and to gain the necessary strength to deliver the charms. In all these steps, we can observe how the tedai participates actively in his/her preparation through an embodied engagement with the world. The tedai may need to free his/her mind from any thought in order to prepare him/herself for the performative act (Siragusa, fieldnotes 2013). Some may use scissors to cut/ create a space around themselves before performing (Siragusa and Zhukova 2018). They may also temporarily abstain from social interaction with other people and any chores they would otherwise engage in. Once ready to deliver the charm, they go and choose explicit places where to perform. If an issue arose in the house, for example, the charm may be performed there (Siragusa, fieldnotes 2013). The tedai may choose to sit at a crossroads to blow specific words out in the air towards the forest when a request needs to reach out to the mec(a)ižand (Siragusa, fieldnotes 2013, 2015). Sometimes, they may also use the chimney as a means to blow the words into the open space (Siragusa, fieldnotes 2013). Certain morphological features of the forest, such as the shape and number of the branches on a tree, the position of the sun, the direction of the wind, may need to be present if a request is going to be performed there (KRC-RAN 19-2662-25). Specific steps must also be taken once the verbal charm has been performed. Upon their return from the forest, for example, the tedajad should not look back nor talk to anyone they meet on the way home (Siragusa, fieldnotes 2013). The execution of any verbal charms will often leave the tedai quite exhausted. Yet, we were told that if summoned anew, he/she will not refuse to comply with the request (Siragusa and Zhukova, fieldnotes 2018).

During our interviews or informal conversations, we were told that during the actual delivery of the verbal charm, the tedajad may use objects, tools, liquids, as

4 We use pseudonyms since the people we refer to appear in other papers, where the content is more sensitive. We have thus decided not to disclose their identity. 
well as their own body parts. These are understood to attune with the words and forceful movement of air pushed out of their body through the mouth (Siragusa, fieldnotes 2013, 2015; Siragusa and Zhukova, fieldnotes 2018). These objects enter and continue to endure change upon the completion of the event in unison with the blown words. Hence, what emerges from the descriptions and stories we were told is that the tools used during the performance of the verbal charms should not be represented as simply accompanying and separate from the act of blowing specific words. Change and transformation is possible when the objects, body parts, and different types of tools are attuned with the act of blowing air and uttering specific words, thus creating a new condition, during which the material boundaries between objects, bodies and language are understood to dissolve. In this temporary condition, the specific words and the materials used in the ritual coalesce. We thus approach the events as conditions and processes in which material boundaries are understood to be temporarily permeable. When one performs a charm, it is not the power of the words that are being passed on, but it is as if different materials coalesce.

Here, we present an episode which required the use of objects, tools, liquids, and body parts and in which Lara Mironova narrated to Laura. While sharing details of the episode, Lara Mironova decided not to disclose the actual words of the verbal charm, since these are passed on only once, when the tedai decides not to execute them any longer. While recollecting an event in which she witnessed an old lady perform a charm, Lara Mironova mimicked the performer's actions and said:

This old lady would come to see you [i.e., anyone who had a problem with his or her eyes] and ask if [the health issue] had started inside the house or in the street. If you answered that it had started in the morning, then it meant inside the house. So, she would execute [a verbal charm] inside the house. She would find herself a place where to sit and whisper, whisper, and then turn to the eyes [of the sick person]. [Siragusa, fieldnotes 2013]

The old lady whispered onto her own hands and then turned to the ill person, touched the inflicted person's eyes with her hands, and finally moved her hands from the periphery of the eyes towards the nose. The person who had been treated would experience full recovery the morning after. ${ }^{5}$ Other Veps mentioned using a piece of cloth, water, wine, metallic objects, smetana (sour cream), and other substances. With reference to the use of smetana, Ol'ga's grandmother told her that when the tedai cannot go in person to visit the sick person, he or she may blow the words on the sour cream and ask someone else to take it in a container. Yet, if a river or stream has to be crossed, the courier should protect the smetana by saying

5 Sometimes the verbal charms can be performed on the body parts of the person who is seeking help, as Rivers (1924) also points out. He refers to this as "sympathetic magic." 
some words - this is because the water can reduce the effectiveness of the charm (Zhukova, fieldnotes 2020). Vepsian ontology around verbal charms indicates that matter, movement of air, and words attune and resonate together, and, thus, create a new, more plastic condition in which material change and transformation in people and the environment are possible. The result of the verbal charms may take place overnight, or it may take longer. During an informal discussion with a colleague from Russia, who is also an ethnographer and thus will be kept anonymous, our colleague recollected being hit on the head, which caused concussion during a field trip. Admittedly, the trip did not occur in a Vepsian village, but among Russians in Karelia, where some practices and their symbolism come very close to those of Veps. Being in a remote village, away from any clinic or hospital, the locals suggested visiting a knowledgeable person to get treated. After blowing the powerful words, the knowledgeable person fastened a bandage around our colleague's head and handed some other substance to apply during the trip back home. Once at the hospital in town and to the surprise of the doctors, our colleague had fully recovered.

We now present a couple of texts to exemplify some of their structural features that illustrate our main argument. We have decided to provide a couple of verbal healing charms concerning a hernia (but also, more broadly a sickness or disease), given how frequently these puheged are found both in the phono-archives at the Academy of Sciences in Petrozavodsk and in the villages. The first comes from a recording in the archives and the second from Ol'ga's personal fieldwork and archive:

Puren minä necen purendan i häkutesen

ezmeižuu hambhou puren, tagaižou hambhou

tačin tehe tropatomha, soho

samlotomha, merhe

pohjatomha, tatatomaks, mamatomaks,

rodutomaks, plodutomaks i tämäks igaks kaikeks.

Pähuden purendan, har'goižiden purendan, nižaižiden purendan, vacaižen purendan, nabaižen purendan, k’oukuižiden (g’ougaižiden)
I gnaw this hernia/disease and hernia/ disease away, and I bite with the first tooth, I throw [it] away with the back tooth onto the road where

there's no path, into the swamp where there's

no moss, into the sea where there's no

bottom, without a father, without a mother without kindred, fruitless, and forever

Hernia/disease of the head, hernia/ disease of 
purendan, kandoižiden purendan

mladencau i

očišaju i izbavlaju neciš purendaspäi

häkutusespäi tämäs päiväs, tämäs časus igaks

kaikeks, amin'. the shoulders, hernia/disease of the chest hernia/disease of the belly, hernia/ disease of

the belly button, hernia/disease of the legs

hernia/disease of the knees [I take you away]

I cleanse and get rid of this hernia/ disease

and hernia/disease from this youngster (name) on this very day, on this very hour

forever. Amen.

[MRC-RAN 3-625-7]

In this verbal charm, the terms used to indicate the "hernia" are pureb/purend and häkutez. As for the first term, it is etymologically related to the Vepsian verb purda (to bite, to gnaw). Indeed, it is expected that "knowledgeable women" bite the hernia away by blowing those specific words (Zhukova 2019: 317). This reveals the deeply physical and material engagement of the act of "blowing specific words" and the relevance of the mouth as a place where change begins. The word pureb means both hernia and a disease in the Vepsian language, or sickness more generally. The term häkutez, however, is a word that is not present in the current Vepsian lexical repertoire, and has only been preserved in such ritualized texts, which makes them even more valuable for linguistic investigation. Etymologically linked to the verb häkätada (to suffocate, to heavily breathe), häkutez literally means "breathlessness" (Zhukova 2019: 317). The fact that two synonyms are repeated at the beginning and the end of the charm is a common stylistic characteristic of such folkloric texts, since repetition reinforces the meaning of what is being said.

Panimoi blaslovas,

Nuuzin blaslovas, ühten jougan kengin pölusuu, toižen jougan kengin kündusuu, Ukses ukshe, Verejas verejaha, Lagedaha püudho,
I lay blessing,

I rise blessing,

One leg on the pillow,

The other on the threshold,

Door to door,

Gate to gate,

To an open field, 
Vihandaha normhe, Lagedas püudos, Vihandas normes Om maho lähtei. Nece maho lähtei nühtib vihandan normen,

muga nühtib rababožjou

Necen pure-kibun

Raba božjou ... (nimi)

Igäks keikeks.
To a green meadow,

In the open field, In the green meadow, There is a farrow chick That farrow chick pulls the green meadow, And so we pull this hernia out of this servant of God,

This servant of God ... (name).

Forever.

Amen, amen, amen.

Amin', amin', amin'.

Zhukova personal archive. 2017. Kurb. Zhukova interviewed her grandmother G. P. Eršova (1933-).

While puheged are mostly aimed to settle human-to-human relations, vajhed/ pakitas are used in relation to non-human beings, such as the territory masters, as a way to affect jointly the course of life in a way that is beneficial to humans.

\section{Conclusion}

In August 2018, on our last day in Radogoshch' - a village of the southern Veps - we decided to visit Maria Maksimova (pseudonym) (early-60s), who we had been told was well versed in puheged and vajhed/pakitas. We had been waiting to go and visit her until the end of our stay, since we had heard that she had been bitten by a snake and had almost risked her life right before our visit to the village. As soon as we entered her house, we asked her how she was doing. She showed no discomfort in revealing that she had to rush to the closest clinic as executing a puheg on herself is not as effective as performing it for others, thus immediately disclosing her knowledge of the verbal charms. Maria Maksimova, now retired, told us that she used to be a nurse at a hospital and that she would perform a spell on the sick person when she thought this might help. From her stories, we understood that she saw no opposition in the verbal healing practices she had learned in the village and those she had learned during her medical training. On the contrary, they could complement each other and, if anything, bring only benefits to those in need.

Besides Maria Maksimova's story, we had heard from others tedajad that they still execute puheged and vajhed/pakitas. So, contrary to what is often assumed that verbal charms, spells enchantments, and similar folkloric genres are 
disappearing and often belong to the past, as part of a long-gone "traditional knowledge," we observed that these practices still endure. Admittedly, Laura had only witnessed the use of vajhed/pakitas, whereas, Ol'ga had also witnessed the use of puheged when living in the village. The dynamicity of these folkloric genres can be witnessed not only in the oral mode of the Vepsian language, in particular in rural areas, but also in its written mode, which has been advanced and promoted since the late 1980s. For example, some Vepsian authors, such as Alevtina Andreeva (1938-2001), experiment with their styles and creatively provide a new form for the charms. ${ }^{6}$

With our article, we aimed to present ways of dwelling in a northern territory together with human and non-human agencies through the performance of ritualized verbal charms, which are both dynamic and relational. Not only is their use molded in relation to changes in the socio-political and ideological ecology, but also through their study we can reflect on the multiple ways of being which shape the world we currently live in. Through an analysis of puheged and vajhed/pakitas, we have been able to engage in current scholarly debates on the separation between language and materiality and to a certain extent break its polarity, which has proven so difficult to penetrate and problematize. In the event of Vepsian verbal charms, blowing specific words is understood to join matters and coalesce human and nonhuman agencies for it to be forged and reshaped. The division between "language" and "materiality" seems somewhat superfluous when approaching (often indigenous) "language ontologies" and metaphors of language (cf. Ferguson 2019; Siragusa 2017), which do not match dominant so-called "Western" ones, as they are often understood to be fluid, relational, and adaptable. The act of "blowing specific words," the movement of air, the coming together of human and non-human forces are understood to shake the material boundaries between language and the world and, thus, spur social change.

Ours is not a cynical appropriation of indigenous knowledge for the benefit of neoliberal governmentality, nor is it an attempt to present different ways of being in the world as possible alternatives to save us from recurrent crises (Chandler and Reid 2018). What we strive for in this paper is to deepen our understanding of what living relationally means. For us, this presupposes reconsidering the dualism between language and materiality through an analysis of verbal charms, which besides their textual and linguistic value, are studied for their social and relational qualities.

6 See, for example, the poem, entitled "Spell-casting words stop the bleeding” in Vepsy (p. 356, https://www.booksite.ru/folk/data/veps.pdf). 


\section{Archives}

Phono-archives at the Karelian Research Centre of the Russian Academy of Sciences in Petrozavodsk (KRC-RAN).

Journal 3, tape 625, file no. 7. 1965. Pondal. M. I. Mullonen interviewed E. N. Kosheva. (KRC-RAN 3-625-7)

Journal 19, tape 2662, file no. 25. 1981. Pondal. Onegina interviewed A. L. Kalinina (KRC-RAN 19-2662-25)

Journal 19, tape 2663, file no. 22. 1981 Pondal. Onegina interviewed A. L. Kalinina. (KRC-RAN 19-2663-22)

Acknowledgments: We would like to thank our field collaborators for sharing their time, knowledge and practices with us. We would also like to express our infinite gratitude to the Director of the phono-archives at RAS Petrozavodsk, Valentina Kuznetsova, for kindly giving us untranscribed material. Thanks very much to the reviewers for their very useful comments.

Research funding: Our work was supported by the Humanities Program at the Faculty of Arts, University of Helsinki, and by the KONE Foundation, NORMAL [grant number 201805889, 2018]. Fieldwork was also supported by the ERC Advanced Grant, Arctic Domus [grant number 295458, 2011].

\section{Appendix}

This research and the content of this paper emerge from our spontaneous collaborative work. We are scholars, one of which is non-indigenous (Laura Siragusa) and the other indigenous (Ol'ga Zhukova), who met in 2009 during Laura Siragusa's first fieldwork in the Republic of Karelia, Russia. Indicating that one of us is indigenous and the other is not does not draw on the engagement with the more politically and ethically oriented debates about "collaborative methodologies" within indigenous studies frameworks (cf. Kovach 2009; Tuhiwai Smith 1999). Rather, it aims to alert the readers that our academic cooperation was spurred spontaneously on the realization that "the other" - that is, any one of us - was socialized in the world differently, knew something different, approached relations with humans and nonhumans differently, dwelled in the world differently, was given a different history and ecology, and thus we could both learn from one another. Indeed, since 2009, we have not only developed a close friendship, but also compared our knowledge and realized that our scholarly interests often overlap. Laura Siragusa is Italian and has a background in Anthropology, with a particular focus on Linguistic Anthropology. She obtained her PhD in Anthropology in Scotland. Whereas Ol'ga Zhukova is Veps 
and a Russian citizen and has received training in Folklore Studies and Linguistics in Russia. We became interested in Vepsian verbal charms separately, but soon discovered that we could cooperate, relying on each other's strengths. For Laura, interest in verbal charms grew out of a project on healing practices that started in 2013. Ol'ga became acquainted with verbal charms in her childhood, when her grandmother, who did not know any fairy-tales or lullabies, used to recite the verbal charms as a strategy to send her to sleep. In 2013, Laura visited the Academy of Sciences, where Ol'ga works. There, the director of the phono-archives, Valentina Kuznetsova, kindly provided her with archival un-transcribed tapes where verbal charms from the 1960s onwards had been stored. That was the moment when Ol'ga and Laura contemplated joining forces. The present work is based on individual trips to villages in all administrative regions where Veps live, archival material from the phono-archives in Petrozavodsk, as well as a joint field work experience we shared in summer 2018. Given our heterogeneous experiences and approaches, our observations have made us reflect, in miscellaneous ways, on the significance as well as ecological and relational use of Vepsian verbal charms, which we have indicated throughout the article.

\section{References}

Agapkina, Tatiana A., Levkievskaya, Elena E. \& Andrei L Toporkov. 2003. Polesskiye zagovory (vzapisyakh 1970-1990-kh gg.) [Verbal charms from Polessk (from the recordings in the 1970s-90s)]. Moscow: Indrik.

Arzyutov, Dmitry V. 2019. Environmental encounters: Woolly mammoth, indigenous communities and metropolitan scientists in the Soviet Arctic. Polar Record 55. 142-153.

Barua, Maan. 2016. Encounter. Environmental Humanities 7. 265-270.

Bird-David, Nurit. 1999. 'Animism' revisited; personhood, environment, and relational epistemology. Current Anthropology 40(S1). S67-S91.

Bogoraz, Vladimir G. 2019. Evolutsiya Religioznykh Verovaniy. Kurs Lektsiy (1927-1928 gg). [The evolution of religious beliefs. Lecture Course (1927-1928)]. St. Petersburg: St. Petersburg State University Publishing House.

Brightman, Marc, Grotti, Vanessa E. \& Olga Ulturgasheva. 2012. Introduction - animism and invisible worlds: The place of non-humans in indigenous ontologies. In Marc Brightman, Vanessa Grotti \& Olga Ulturgasheva (eds.), Animism in rainforest and tundra: Personhood, animals, plants and things in contemporary Amazonia and Siberia, 1-27. New York: Berghahn.

Cavanaugh, Jillian \& Shalini Shankar (eds.). 2017. Language and materiality: Ethnographic and theoretical explorations. Cambridge: Cambridge University Press.

Chandler, David \& Julian Reid. 2018. 'Being in being': Contesting the ontopolitics of indigeneity. The European Legacy 23(3). 251-268.

de Castro, Eduardo Viveiros. 1998. Cosmological deixis and Amerindian perspectivism. Journal of the Royal Anthropological Institute 4(3). 469-488. 
Descola, Philip. 2014. Modes of being and forms of predication. HAU: Journal of Ethnographic Theory 4(1). 271-280.

Desjarlais, Robert R. 1996. Presence. In Carol Laderman \& Marina Roseman (eds.), The performance of healing, 143-164. New York and London: Routledge.

Evans-Pritchard, Edward E. 1956. Nuer religion. Oxford: Clarendon Press.

Favret-Saada, Jeanne. 2015[2009]. The anti-witch. Translated by Matthew Carey. Chicago: HAU Books.

Ferguson, Jenanne. 2019. Words like birds: Sakha language discourses and practices in the city. Lincoln and London: Nebraska University Press.

Fienup-Riordan, Ann. 1994. Boundaries and passages: Rule and ritual in Yup'ik Eskimo oral tradition. Norman: University of Oklahoma Press.

Frog. 2013. Shamans, christians, and things in between: From Finnic-Germanic contacts to the conversion of Karelia. In Leszek Słupecki \& Rudolf Simek (eds.), Conversions: Looking for ideological change in the early middle ages, 53-98. Studia Mediaevalia Septentrionalia 23. Vienna: Fassbaender.

Gal, Susan. 1991. Between speech and silence: The problematics of research on language and gender. In Micæla Di Leonardo (ed.), Gender at the crossroads of knowledge, 175-203. Berkeley: University of California Press.

Golopentia, Sanda. 2004. Towards a typology of Romanian love. In Jonathan Roper (ed.), Charms and charming in Europe, 145-187. New York: Palgrave Macmillan.

Handelman, Don. 2005. Ritual in its own right: Exploring the dynamics of transformation. In Don Handelman \& Galina Lindquist (eds.), Ritual in its own right: Exploring the dynamics of transformation. New York: Berghahn Books.

High, Casey. 2018. Bodies that speak: Languages of differentiation and becoming in Amazonia. Language \& Communication 63. 65-75.

Hull, Matthew. 2003. The file: Agency, authority, and autography in an Islamabad bureaucracy. Language \& Communication 23. 287-314.

Irvine, Judith T. 2005. Knots and tears in the interdiscursive fabric. Journal of Linguistic Anthropology 15(1). 72-80.

Irvine, Judith T. 2017. Afterword: Materiality and language, or material language? Dualisms and embodiments. In Jillian Cavanaugh and Shalini Shankar (eds.), Language and materiality: Ethnographic and theoretical explorations, 277-293. Cambridge: Cambridge University Press.

Ivanits, Linda J. 1989. Russian folk belief. London: ME Sharpe.

Kapferer, Bruce. 2015. Introduction. In the event-toward an Anthropology of generic moments. In Lotte Meinert \& Bruce Kapferer (eds.), In the event: Toward an anthropology of generic moments, 1-28. New York and Oxford: Berghahn Books.

Keane, Webb. 2003. Semiotics and the social analysis of material things. Language \& Communication 23(3-4). 409-425.

Keane, Webb. 2008a. Market, materiality and moral metalanguage. Anthropological Theory 8(1). 27-42.

Keane, Webb. 2008b. The evidence of the senses and the materiality of religion. Journal of the Royal Anthropological Institute 14(s1). S110-S127.

Keane, Webb. 2013. On spirit writing: Materialities of language and the religious work of transduction. Journal of the Royal Anthropological Institute 19(1). 1-17.

Kockelman, Paul. 2006. A semiotic ontology of the commodity. Journal of Linguistic Anthropology 16(1). 76-102. 
Kovach, Margaret. 2009. Indigenous methodologies: Characteristics, conversations, and contexts. Toronto: University of Toronto Press.

Kroskrity, Paul V. (ed.). 2000. Regimes of language. Ideologies, politics, and identities. Santa Fe: School of American Research Press/Oxford: James Currey.

Latour, Bruno. 2009. Perspectivism: 'Type' or 'bomb’? Anthropology Today 25(2). 1-2.

Lavonen, Nina A. 1988. Zagovory v krugu religiozno-magicheskikh predstavleniy karel (po materialam ekspeditsiy 1975-1984 gg.) [Verbal charms in religious-magical performances among Karelians (based on field trip material between 1975 and 1984)]. In Zinaida Iv Strogal'shchikova (ed.), Obryady i verovaniya narodov Karelii [Rituals and belief of the peoples of Karelia], 130-139. Petrozavodsk: Karel'skyi Filial AN SSSR.

Makar’yev, Stepan. 1932. Vepsy: etnograficheskiye ocherki [Veps: Ethnographic studies]. Leningrad: Kiriya.

Malinowski, Bronistaw. 1922. Argonauts of the Western Pacifics. An account of a native enterprise and adventure in the archipelagoes of Melanesian New Guinea. London: Routledge.

Malinowski, Bronistaw. 1935. Coral gardens and their magic. A study of the methods of tilling the soil and of agricultural rites in the Trobriand Islands. Vol. I. New York, Cincinnati, Chicago: American Book Company.

Mauss, Marcel. 2001[1950]. A general theory of magic. London and New York: Routledge Classics.

Nakassis, Constantine. 2013. Materiality, materialization. HAU: Journal of Ethnographic Theory 3(3). 399-406.

Panina, Tatiana I. 2014. Slovo i ritual $v$ narodnoy meditsine udmurtov [Word and ritual in traditional medicine among Udmurts]. Izhevsk: RAN.

Prost, Audrey. 2008. Precious pills: Medicine and social change among Tibetan refugees in India. Oxford: Berghahn Books.

Puura, Ulriikka. 2018. Language modes and conversational code-switching in contemporary Veps - a microanalysis. In Magdolna Kovács \& Ulriikka Puura (eds.), Multilingual practices in Finno-Ugric communities, 263-296. Helsinki: Uralica Helsiengiensa 13.

Rahman, Elizabeth \& Bernd Brabec de Mori. 2020. Breathing song and smoke: Ritual intentionality and the sustenance of an interaffective realm. Body \& Society 26(2). 130-157.

Rivers, William H. R. 1924. Medicine, magic, and religion. In The Fitzpatrick Lectures delivered before the Royal College of Physicians of London in 1915 and 1916. London and New York: Routledge.

Ryan, William F. 2004. Eclecticism in the Russian charm tradition. In Jonathan Roper (ed.), Charms and charming in Europe, 113-127. New York: Palgrave.

Schieffelin Bambi B., Woolard Kathryn A. \& Kroskrity Paul V. (eds.). 1998. Language ideologies: Practice and theory. New York: Oxford University Press.

Shankar, Shalini \& Jillian R. Cavanaugh. 2012. Language and materiality in global capitalism. Annual Review of Anthropology 41. 355-369.

Silverstein, Michael. 2003. Indexical order and the dialectics of sociolinguistic life. Language \& Communication 23(2-3). 193-230.

Silverstein, Michael \& Greg Urban (eds.). 1996. Natural histories of discourse. Chicago: University of Chicago Press.

Siragusa, Laura. 2011. Fieldnotes. Vepsian villages and Petrozavodsk in Karelia.

Siragusa, Laura. 2013. Fieldnotes. Pondala.

Siragusa, Laura. 2015. Fieldnotes. Pondala.

Siragusa, Laura. 2017. Promoting heritage language in Northwest Russia. London and New York: Routledge. 
Siragusa, Laura \& Olga yu, Zhukova. 2018. Fieldnotes. Radogoshch.

Siragusa, Laura, Westman, Clinton N. \& Sarah Carmen Moritz. 2020. Shared breath: Human and non-human co-presence through ritualized words and beyond. Current Anthropology 61(4): 471-494.

SSA. 1995. Suomen Sanojen Alkuperä: etymologinen sanakirja, vol. II. Helsinki: SKS Kotimaisten Kielten Tutkimuskesus.

Stark-Arola, Laura. 1998. Magic, body and social order. The construction of gender through women's private rituals in traditional Finland. Helsinki: Finnish Literature Society.

Stewart, Pamela J. \& Andrew Strathern. 2004. Witchcraft, sorcery, rumors, and gossip. Cambridge: Cambridge University Press.

Strogal'shchikova, Zinaida Iv. 1988. Materialy po rodil'noy obryadnosti vepsov [Materils on birth rituals among Veps]. In Zinaida Iv Strogal'shchikova (ed.), Obryady i verovaniya narodov Karelii [Rituals and belief of the peoples of Karelia], 95-106. Petrozavodsk: Karel'skyi Filial AN SSSR.

Strogal'shchikova, Zinaida Iv. 2016. Vepsy v etnokul'turnom prostranstve evropeyskogo severa [Veps in the ethno-cultural landscape of the European north]. Petrozavodsk: Periodika.

Taylor, Anne-Christine. 2013. Healing translations: Moving between worlds in Achuar shamanism. HAU Journal of Ethnographic Theory 4(1). 95-118.

Toporkov, Andrei. 2012. Verbal charms from a seventeenth-century Russian manuscript. Incantatio 2. 42-54.

Tuhiwai Smith, Linda. 1999. Decolonizing methodologies: Research and indigenous peoples. London and New York: Zed Books Limited.

Vinokurova, Irina Yu. 2010. Voda vepsskikh mifologicheskikh predstavleniyakh o zhizni i smerti [Water in Vepsian mythology]. Trudy Karel'skogo nauchnogo tsentra RAN 4. 66-76.

Weidman, Amanda. 2014. Anthropology and voice. Annual Review of Anthropology 43. 37-51.

Weiner, Annette B. 1983. From words to objects to magic: Hard words and the boundaries of social interaction. Man 18(4). 690-709.

Wiener, Margaret J. 2013. Magic, (colonial) science and science studies. Social Anthropology 21(4). 492-509.

Willerslev, Rane. 2007. Soul hunters: Hunting, animism, and personhood among the Siberian Yukaghirs. Berkeley: University of California Press.

Zhukova, Ol'ga. 2019. Imenovaniya ponyatiya "gryzha" [Naming the concept of "hernia"]. In Nina G. Zaitseva (ed.), Lingvisticheskiy atlas vepsskogo yazyka [Linguistic atlas of Vepsian language], 316-318. Saint-Petersburg: Nestor-Istoriya.

Zhukova, Ol'ga Yu. 2020. Fieldnotes. Kurba. 